\title{
1
}

\section{External Actors and Social Protection in the Global South: An Overview}

\author{
Carina Schmitt
}

\section{Introduction}

In recent times, social protection has been one of the most popular instruments for promoting human development in the Global South. ${ }^{1}$ Understanding contemporary social protection in countries of the Global South requires a deep comprehension of its historical roots and the conditions under which welfare institutions emerged. However, as most research on social protection continues to focus on the Organisation for Economic Co-operation and Development (OECD) world, our knowledge of drivers, characteristics and outcomes of social protection in the Global South is still limited. The existing narrative of welfare state emergence, developed

\footnotetext{
${ }^{1}$ Global South is not a clearly defined term in the literature. In this book volume, we follow the definition by the UN and the World Bank which use the term for low- and middle-income countries.
}

C. Schmitt $(\bowtie)$

SOCIUM Research Center on Inequality and Social Policy,

University of Bremen, Bremen, Germany

e-mail: carina.schmitt@uni-bremen.de

C. Schmitt (ed.), From Colonialism to International Aid, Global Dynamics of Social

Policy, https://doi.org/10.1007/978-3-030-38200-1_1 
for rich democracies with an emphasis on domestic structural conditions and national actors, provides only partial insight into the emergence and structure of social protection systems in other regions of the world. Several studies analyzing social protection in the Global South have emphasized the influence of external national and transnational actors for contemporary social policy-making (Kaasch and Martens 2015; Yeates 2009; Deacon 2007). International bilateral donors, multilateral agencies, international financial institutions, non-governmental organizations (NGOs) and influential nation states are assumed to influence social protection pathways in the Global South.

However, the transnational nature of social protection arrangements in the Global South is also not a new phenomenon. From the very beginning, when social protection was put on the global agenda, especially during and after World War II, social protection arrangements in the Global South have been shaped by external actors. In those days, the international landscape was still characterized by colonial empires (Abernethy 2000), and the great majority of countries in the Global South were still dependent territories. In the course of the twentieth century, colonial powers became more and more engaged in social policies in their colonies because of the pressure from inside the colonies in the form of rising demands for social protection, but also from the outside in the form of soft pressure by international organizations (Schmitt 2015). Following the end of the colonial era and the process of decolonization, the former colonies and other countries of the Global South became major battlegrounds for regime competition between the capitalist and the communist regime during the Cold War. The US, China and the Soviet Union as big global powers tried to bring the emerging nation states into their respective influential spheres. Hence, social policymaking in those days was interfered by the interests and interventions of colonial empires or the communist and Western superpowers.

The influence of external actors did not stop with the end of the Cold War. Even today, social protection in the Global South is influenced by interests and paradigms of international organizations and donors, such as the International Labour Organization (ILO) and the World Bank. Due to their financial resources and administrative capacity, these actors often support social protection programs and legislations 
(Kott and Droux 2013; Surender 2013). In fact, international actors have been the "primary and most consistent advocates for expansionism [of social protection, the editor] across the developing world" (Rudra 2015, 464).

However, not all countries react to external pressure in the same way. Social policy models pushed and promoted by external actors have not been simply translated into national policies and institutions but have rather been adapted, mediated and transformed according to national and local conditions. Policy-makers in the Global South have had to find ways of managing, negotiating and asserting themselves when designing social protection systems in a context where often more powerful external actors have been present from the outset. In some countries, national policy-makers withstand the pressure exerted by external actors or even explicitly deviate from policies they were supposed to implement by external actors. Whether and how external actors shape social protection is therefore conditioned by the strength of local political parties, labor unions, but also by domestic financial, administrative and political circumstances. It is therefore important to consider the interplay between external actors and national factors when analyzing social protection pathways in countries of the Global South.

But what exactly does the influence of external actors look like? And how is the influence translated by national factors? Do external actors really shape social protection pathways in a significant way or is their influence overemphasized?

In this volume, we ask whether and how external actors and transnational relationships have influenced the formation, development and transformation of social protection in the developing world. We use a broad definition of social protection, including health and education policies, but also, for example, famine relief and food security programs. A broad definition is more suitable for covering the range of social protection programs existent in the Global South which goes beyond the classical social security programs mainly introduced in Western countries. The edited volume addresses the need to systematically integrate external actors into the narrative of social policy-making in the Global South to enhance our understanding and knowledge of welfare institutions in regions beyond the OECD. 
In this book, we focus on a selective range of actors to make cross-case comparisons possible. We elucidate the influence of colonial and Cold War superpowers as examples of the long-lasting influence of external actors on social protection pathways. The book provides insights into how colonial powers and the Cold War superpowers shaped social protection arrangements, for example in order to serve their objectives such as fighting communism or maintain the imperial order. Moreover, we focus on the role of international donors and international financial institutions as the most important contemporary external actors developing and promoting social policies in the Global South. In this volume, scholars applying quantitative frameworks are brought together with others using qualitative techniques. The quantitative analyses provide broad brush pictures that are necessary for evaluating the role of external actors in the transnational social protection arrangements for a larger country sample. The qualitative case studies, in contrast, are essential for identifying how external actors have to be integrated into the social protection actor network, how they intervene in social protection-making, but also to assess the limitations of their influence. We moreover combine historical as well as social science approaches to show how social protection arrangements have ever since been shaped by external actors. This is especially important as knowledge is scarce when analyzing the influence of external actors further back in history. The edited volume furthermore contributes to the literature by explicitly analyzing the interplay between external actors and national conditions as well as by critically assessing the explanatory power of external actors for social protection pathways in the Global South. The volume shows that social policy-making in most countries of the Global South has never been a strictly national story. External actors have been part of social protection decisions from the very outset. However, the influence of external actors has always been translated by national actors and domestic circumstances into social policies and institutions. After all, the volume offers a critical assessment of the role of external actors and discusses ideational and institutional approaches to systematically integrate external actors into the domestic arena of social protection-making in the Global South. 


\section{External Actors and Social Protection in the Global South: State of the Art}

The field of social protection in the Global South has attracted growing interest of scholars since the beginning of this century. Several scholars have in the meantime outlined and discussed social protection trajectories in the Global South and provided valuable insights into different social protection pathways in different regions of the world (e.g. Haggard and Kaufman 2008; Huber and Stephens 2012; Rudra 2008; Gough and Wood 2004; Barrientos 2013; Surender and Walker 2013; Midgley and Piachaud 2011). They show that most countries in the Global South have implemented social insurance programs in the first place and demonstrate how social assistance programs have in recent decades spread across countries (Schmitt, Chap. 6, this volume). These studies, mainly stemming from Comparative social policy research, emphasize the role of national actors in social policy-making. Differences in national social protection trajectories have been mainly traced back to different national actor constellations and class coalition building processes. The power resource theory (Korpi 1983) and the closely related partisan theory (Hibbs 1977) argue that labor unions and political parties shape social policy dynamics. Strong left power resources in the executive and legislative are assumed to be key drivers of generous social protection schemes (Castles 1978). Partisan theory (Castles 1982; Schmidt 1982) additionally stresses the importance of Christian democratic parties and political Catholicism for encompassing social policies (van Kersbergen 1995; van Kersbergen and Manow 2009; Manow 2015). Furthermore, the political economy literature argues that political leaders make use of public policies in general and social policies in particular to create winning coalitions and secure regime survival (Knutsen and Rasmussen 2014). In this view, social protection is an important instrument for governments, especially in authoritarian contexts of non-liberal states, to secure elite privileges in recompense for political loyalty and to legitimate the political system (Magaloni et al. 2007; Rudra and Haggard 2005; Wibbels and Ahlquist 2011). Research on non-Western countries additionally emphasizes that substantial cross-national differences in social policy 
priorities are related to distinct post-war development strategies, such as import-substitution industrialization and export-oriented industrialization (Rudra 2002, 2007, 2008; Avelino et al. 2005; Barrientos and Santibáñez 2009; Wibbels and Ahlquist 2011). In the context of this tradition, external actors have not been systematically considered or only in a very general and superficial way.

Global social policy as another relevant strand of literature for this book volume, in contrast, takes external actors as the point of departure. Global social policy research has drawn our attention to a broad array of individual and corporate global social policy actors, ranging from internationally operating intergovernmental organizations, in particular the World Bank (Orenstein 2010), the ILO (Supiot 2006; Maupain 2009; Deacon 2013), the OECD (Mahon 2009; Martens and Jakobi 2010) or the EU (Walkenhorst 2008; Lamping and Steffen 2009; Natali 2009), to states formations, such as the G20, as well as South-South relations such as BRICS (Surender 2013) and to NGOs (Martens and Kruse 2015; Stubbs 2003) or business actors (Farnsworth 2012). Studies in this field elucidate the role of international, supranational and transnational organizations. They address the questions of how these organizations have shaped international standards and norms regarding social policy and how these global norms and recommendations feed into the domestic social policy arena (Orenstein 2010; Yeates 2009; Deacon 2013, 2007; Kaasch and Martens 2015). One major strong point of global social policy research is that it has brought forward scholarship on how international organizations produce and disseminate policy ideas across countries and regions. Some contributions, often based on constructivist approaches, have developed conceptualizations of how international organizations exert influence, taking into account that most international organizations, in particular in the field of social policy, are not able to apply hard governance but rather use soft governance mechanisms (Abbott and Snidal 2000). Global social policy research has advanced the understanding that social issues transcend borders, explaining why international organizations can be influential actors (Hulme and Hulme 2008; Jenson 2010). However, the interdependencies between actors at the global and national level have been neither fully grasped in a coherent conceptual manner nor comprehensively and systematically in their empirical existence. Nevertheless, global social policy research reveals the 
tension between the global perspective of social problem identification and the implementation of social policies at the national level, which we take up in this paper.

In sum, the existing literature offers valuable insights to understand social protection in contexts where powerful external actors have been present from the very outset. However, in each individual case and isolated from each other these approaches are not sufficient for capturing and appropriately situating all actors that are relevant for social protection arrangements. Comparative social policy research mainly focuses on national actors and their preferences and, if at all, only very roughly integrates external economic and political influences. In contrast, global social policy research rather focuses on transnational and international actors relevant for social protection without elucidating domestic politics at the national level. It mainly analyzes the influence of external actors from the perspective of the international organizations, but not from the perspective of the developing countries themselves. What is missing are studies linking both strands of research. Moreover, most of the studies focus on contemporary external actors and social protection, while the historical dimension of external influences on social protection, such as colonialism and Cold War, is almost completely left out of the equation in both strands of literature (e.g. Deacon 2007; Brooks 2015; Rudra 2008) Hence, even though scholars across a range of disciplines have acknowledged and demonstrated the inherently transnational nature of social protection arrangements, our knowledge of the potential and limits of external national and transnational actors as explanatory factors and drivers of social policy-making in the Global South is scarce. This especially applies when going further back in history, to the mid-twentieth century when social protection was put on the global agenda. This volume contributes to existing scholarship by addressing the mentioned shortcomings. In contrast to the existing work, it explicitly focuses on the role of external actors in different periods of time and in relationship to each national context. The book integrates external actors and their interplay with national conditions into the narrative of social policymaking in the Global South to understand the conditions under which social protection has emerged historically and is expanding in the developing world today. 


\section{External Actors from Colonialism to International Aid: Types, Strategies and Objectives}

In the literature, different external actors are assumed to influence social protection pathways in the Global South. In this volume we apply a broad notion of what an external actor is. External actors in a broad sense can be understood as collectives of individuals who share an interest in and ability to act together toward a common end. Moreover, they are mainly based outside the territory which they aim to influence (Pontusson 1995; Huber and Stephens 2010). Even though there is no systematic classification of external actors, there are several possible dimensions along which they can be categorized. For example, external actors can be separated according to whether they are governmental or intergovernmental, public or private, or whether they provide technical expertise or financial leverage.

Most of the recent literature within global social policy research, but also within comparative welfare state research, focuses on the role of international donors, international governmental and NGOs. Most of these actors, however, were not always as widely spread as they are today. Especially intergovernmental organizations have been established only in recent decades. When going back further in history, to the colonial and the Cold War era, external actors were very often powerful individual nation states which made use of the power asymmetries to influence policy-making in dependent territories or in their spheres of influence.

Not only the types of actors might have changed over time but also the mechanisms or strategies through which external actors have tried to influence and shape national social protection pathways. Many studies focusing on the role of contemporary international financial institutions, international organizations and governmental donors emphasize the production and spread of knowledge and the provision of technical and financial support (Orenstein 2010; Deacon 2013; Kott and Droux 2013). These strategies can rather be classified as "soft" than as "hard" power instruments, as at least on the surface they do not force domestic actors to implement specific social protection policies against their will. However, during colonial and Cold War times, other strategies might 
have been important. France, for example, imposed the Code du Travail in all its African colonies in 1952. This labor code, strongly related to the social insurance principle, was the basis for initial social security systems in all French African colonies. This strategy can be regarded as a hard form of exerting influence on social protection pathways.

Changes and continuities are not only observable with regard to the type of relevant external actors and their strategies but also with regard to the objectives and preferences connected to social protection. For example, in the aftermath of World War II, the ILO mainly pushed social security legislations strongly related to waged labor. At that time, social security was supposed to protect the worker against risks of unemployment, work accidents, old age or sickness. The colonial powers at least after World War II also emphasized social protection being strongly linked to the workforce. For the superpowers during the Cold War period, however, social reforms often constituted part of anti-communism strategies (Obinger and Schmitt 2011). Nowadays the ILO supports a more social rights-based approach to social protection as it finds expression by the ILO Social Protection Floors Recommendation. The World Bank, in contrast, rather pushes means-tested social assistance. This exemplifies how external actors differ with regard to the specific social protection policies they prefer and with regard to the objectives to be realized by way of social protection.

However, social policy models supported by external actors have almost never been directly translated into national policies and institutions but have rather been adapted, mediated and transformed by national and local conditions. For example, the influence of colonial powers might depend on the domestic factors of the dependent territories, such as economic structure, geographic position and strength of political leaders. In the case of the Cold War superpowers, some political leaders resisted the influence of the Cold War superpowers; others played off both sides against one another, or explicitly deviated from what they were supposed to do. In present times, especially countries that are politically weak or financially dependent might be receptive to the influence of external actors. Tracing this interplay between national conditions and external actors should elucidate some of the domestic framework conditions for the influence of external actors. 
In sum, in this book volume we aim at elucidating changes and continuities with regard to types of external actors, their strategies, objectives and social policy preferences as well as their interplay with national factors, from colonialism to international aid.

\section{Structure of the Book}

This volume contains four parts addressing the long-lasting and contemporary role of external actors for social protection-making in the Global South from the post-war period until today.

Part I provides a systematic introduction to the analysis of external actors of social policy-making in the Global South. Apart from this introduction, then following Chap. 2 by Shriwise addresses existing theoretical approaches to the analysis of external actors and outlines the theoretical implications of understanding social protection in transnational relief.

Part II addresses the long-lasting influence of colonial and Cold War superpowers on early and contemporary social protection-making in developing countries. Part II consists of five chapters. The first three contributions pursue a qualitative approach, while the final two provide statistical analyses. In Chap. 3 Michele Mioni and Klaus Petersen shed light on how social reforms were used as an instrument to fight against the respective competing regime in the early Cold War period. To address this question, the authors historically analyze two Asian countries, that is, Burma and Malaysia. They show how debates on the concepts of welfare and social protection in both countries were influenced and challenged by the Cold War logic. In the subsequent Chap. 4 Daniel Künzler assesses the influence of colonial powers and donors on social protection arrangements, comparing Kenya and Tanzania. Even though both were British colonies, colonial Kenya was considered a labor reserve, whereas Tanzania was rather a cash crop economy for the British officials. Künzler comes to the conclusion that even though both countries follow similar social protection pathways at the first glance, the scope and extent of social policy instruments differ between both countries. In Chap. 5 Jeremy Seekings addresses the role of the British welfare model for social policy-making in colonial and post-colonial times in Botswana and South Africa in the past 
70 years. He demonstrates that in neither South Africa nor Botswana foreign models have been imposed but rather considerably adapted to local norms and conditions. External influences entailed primarily the diffusion of ideas which were combined with local ideas to shape policy outcomes. In Chap. 6 Schmitt addresses the long-lasting influence of the colonial legacy on contemporary social policy-making for a large country sample including around 100 low- and middle-income countries. Applying a quantitative framework, she shows how the recent rise of social assistance in the Global South depends on the colonial heritage of a country. Social assistance programs are by far more frequent in British colonies than elsewhere, while in former French colonies social assistance is almost completely absent. This is traced back to different notions of both colonial powers regarding social protection. In Chap. 7 Becker in his contribution investigates how colonial legacies shape contemporary international aid patterns. He also uses a quantitative framework to answer whether former colonial ties affected aid priorities and whether aid priorities differ between former colonial powers. He demonstrates that former colonial ties become manifest by increased efforts toward supporting social policy projects. Moreover, he shows that these institutional patterns are most visible with regard to the French aid system.

Part III elucidates international donors and international financial institutions as important players in the transnational social policy arena of today. In Chap. 8, by Marina Dodlova, the question of how the World Bank and international donors have influenced the spread of noncontributory social transfer programs throughout the countries of the Global South is addressed. She applies a quantitative framework to analyze how donors drive the diffusion of social policy and how they influence the design of social transfer programs, particularly the targeting method used to determine the beneficiary base. Rahmi Çemen and Erdem Yörük investigate in Chap. 9 whether transnational actors such as the World Bank influence the way in which domestic social unrest is translated into social policy. Their empirical analysis contains a sample of 42 countries from 1989 until 2015. Their results show that efforts on social assistance are larger in countries with high levels of social unrest. In contrast, the influence of the World Bank is limited and only visible in countries with high levels of social unrest. In Chap. 10 Isaac Chinyoka and Marianne Ulriksen analyze how international donors have attempted to influence child welfare policies in 
Botswana. Their analysis highlights that although transnational actors have succeeded with persuading the government in Botswana to change certain policy aspects, they have been unable to fundamentally sway the government to pursue an individual, rights-focused welfare policy paradigm. In Chap. 11 Stephen Devereux and Samuel Kapingidza analyze whether social protection-making is nationally owned or donor-driven. The international development community has invested heavily in propagating social protection policies and programs throughout Africa in the past 20 years. The authors use the case of Zimbabwe to investigate whether donor agendas on social protection are aligned or in conflict with national priorities. They offer several indicators that allow for evaluating whether a social policy process is nationally defined or donor-driven. All contributions in Parts II and III discuss not only the role of external actors for social policy-making but also their interplay with domestic factors.

Part IV critically evaluates the potential and limits of institutionalist and ideational approaches to the influence of transnational actors. It starts with Chap. 12, by Daniel Béland and Priva Haang'andu, who propose an ideational approach for elucidating the influence of transnational actors on social policies. Their proposed framework determines the circumstances under which external actors succeed and/or fail to diffuse transnational norms in an ideationally charged socio-political environment. In Chap. 13 Armando Barrientos critically assesses the influence of external actors and donors in low and middle-income countries. He asks whether donor agencies are actually shaping social assistance institutions in the Global South or whether their influence has been overrated. The dominance of donor organizations and their global policy agendas as opposed to domestic policy has delayed the theorization of the rapid development of welfare institutions in developing countries. The volume is completed by Chap. 14, by Carina Schmitt, Bastian Becker, Judith Ebeling and Amanda Shriwise who summarize the main insights presented by the book. This chapter critically evaluates all contributions of this book volume researching the role of external actors for social protection-making and their interplay with domestic influences. It provides a balanced summary of the relative contributions of external actors and domestic factors to the explanation of social policy-making in the Global South. It also formulates an agenda to inspire future avenues for further research. 


\section{References}

Abbott, Kenneth W., and Duncan Snidal. 2000. Hard and Soft Law in International Governance. International Organization 54 (3): 421-456. https://doi.org/10.1162/002081800551280.

Abernethy, David B. 2000. The Dynamics of Global Dominance: European Overseas Empires, 1415-1980. New Haven, CT: Yale University Press.

Avelino, George, David S. Brown, and Wendy Hunter. 2005. The Effects of Capital Mobility, Trade Openness, and Democracy on Social Spending in Latin America, 1980-1999. American Journal of Political Science 49 (3): 625-641. https://doi.org/10.1111/j.1540-5907.2005.00146.x.

Barrientos, Armando. 2013. Social Assistance in Developing Countries. Cambridge: Cambridge University Press.

Barrientos, Armando, and Claudio Santibáńez. 2009. New Forms of Social Assistance and the Evolution of Social Protection in Latin America. Journal of Latin American Studies 41 (1): 1-26. https://doi.org/10.1017/ S0022216X08005099.

Brooks, Sarah M. 2015. Social Protection for the Poorest: The Adoption of Antipoverty Cash Transfer Programs in the Global South. Politics \& Society 43 (4): 551-582.

Castles, Francis G. 1978. The Social Democratic Image of Society: A Study of the Achievements and Origins of Scandinavian Social Democracy in Comparative Perspective. London, Boston: Routledge \& K. Paul.

., ed. 1982. The Impact of Parties: Politics and Policies in Democratic Capitalist States. London, Beverly Hills, CA: Sage Publications.

Deacon, Bob. 2007. Global Social Policy and Governance. London: SAGE. . 2013. Global Social Policy in the Making: The Foundations of the Social Protection Floor. Bristol: Policy Press.

Farnsworth, Kevin. 2012. Social versus Corporate Welfare: Competing Needs and Interests within the Welfare State. Basingstoke: Palgrave Macmillan.

Gough, Ian, and Geof Wood, eds. 2004. Insecurity and Welfare Regimes in Asia, Africa and Latin America. Cambridge: Cambridge University Press.

Haggard, Stephan, and Robert R. Kaufman. 2008. Development, Democracy, and Welfare States: Latin America, East Asia, and Eastern Europe. Princeton: Princeton University Press.

Hibbs, Douglas A. 1977. Political Parties and Macroeconomic Policy. American Political Science Review 71 (04): 1467-1487. https://doi.org/10.1017/ S0003055400269712. 
Huber, Evelyne, and John D. Stephens. 2010. Development and Crisis of the Welfare State: Parties and Policies in Global Markets. Chicago: University of Chicago Press.

- 2012. Democracy and the Left: Social Policy and Inequality in Latin America. Chicago, IL: University of Chicago Press.

Hulme, Moira, and Rob Hulme. 2008. The International Transfer of Global

Social Policy. In Understanding Global Social Policy, ed. N. Yeates. Bristol:

Policy Press and The Social Policy Association.

Jenson, Jane. 2010. Diffusing Ideas for After Neoliberalism: The Social Investment Perspective in Europe and Latin America. Global Social Policy: An Interdisciplinary Journal of Public Policy and Social Development 10 (1): 59-84. https://doi.org/10.1177/1468018109354813.

Kaasch, Alexandra, and Kerstin Martens, eds. 2015. Actors and Agency in Global Social Governance. Oxford: Oxford University Press.

Knutsen, Carl Henrik, and Magnus Rasmussen. 2014. The Autocratic Welfare State Resource Distribution, Credible Commitments and Political Survival. SSRN Electronic Journal. https://doi.org/10.2139/ssrn.2482593.

Korpi, Walter. 1983. The Democratic Class Struggle. London: Routledge.

Kott, Sandrine, and Joëlle Droux, eds. 2013. Globalizing Social Rights: The Internationalization Labour Organization and Beyond. Edited by ILO, ILO Century Series. Basingstoke: Palgrave Macmillan.

Lamping, Wolfram, and Monika Steffen. 2009. European Union and Health Policy: The "Chaordic" Dynamics of Integration. Social Science Quarterly 90 (5): 1361-1379. https://doi.org/10.1111/j.1540-6237.2009.00659.x.

Magaloni, Beatriz, Alberto Diaz-Cayeros, and Federico Estévez. 2007. Clientelism and Portfolio Diversification: A Model of Electoral Investment with Applications to Mexico. In Patrons, Clients, and Policies: Patterns of Democratic Accountability and Political Competition, ed. Herbert Kitschelt and Steven I. Wilkinson. Cambridge, UK, New York: Cambridge University Press.

Mahon, Rianne. 2009. The OECD's Discourse on the Reconciliation of Work and Family Life. Global Social Policy 9 (2): 183-204.

Manow, Philip. 2015. Workers, Farmers and Catholicism: A History of Political Class Coalitions and the South-European Welfare State Regime. Journal of European Social Policy 25 (1): 32-49. https://doi. org/10.1177/0958928714556969.

Martens, Kerstin, and Anja P. Jakobi. 2010. Mechanisms of OECD Governance. Oxford: Oxford University Press. https://doi.org/10.1093/acprof: oso/9780199591145.001.0001. 
Martens, Kerstin, and Johannes Kruse. 2015. NGOs as Actors in Global Social Governance. In Actors and Agency in Global Social Governance, ed. A. Kaasch and K. Martens, 1st ed. Oxford, UK: Oxford University Press.

Maupain, Francis. 2009. New Foundation or New Facade? The ILO and the 2008 Declaration on Social Justice for a Fair Globalization. European Journal of International Law 20 (3): 823-852. https://doi.org/10.1093/ejil/chp070.

Midgley, James, and David Piachaud, eds. 2011. Colonialism and Welfare. Social Policy and the British Imperial Legacy. Cheltenham: Edward Elgar.

Natali, David. 2009. Pensions in Europe, European Pensions: The Evolution of Pension Policy at National and Supranational Level. New York: P.I.E. Peter Lang.

Obinger, Herbert, and Carina Schmitt. 2011. Guns and Butter? Regime Competition and the Welfare State during the Cold War. World Politics 63 (2): 246-270.

Orenstein, Mitchell A. 2010. Privatizing Pensions: The Transnational Campaign for Social Security Reform. Princeton: Princeton University Press.

Pontusson, Jonas. 1995. From Comparative Public Policy to Political Economy: Putting Political Institutions in Their Place and Taking Interests Seriously. Comparative Political Studies 28 (1): 117-147.

Rudra, Nita. 2002. Globalization and the Decline of the Welfare State in LessDeveloped Countries. International Organization 56 (2): 411-445. https:// doi.org/10.1162/002081802320005522.

- 2007. Welfare States in Developing Countries: Unique or Universal? The Journal of Politics 69 (2): 378-396. https://doi.org/10.1111/j. 1468-2508.2007.00538.x.

2008. Globalization and the Race to the Bottom in Developing Countries: Who Really Gets Hurt? Cambridge, UK, New York: Cambridge University Press. - 2015. Social Protection in the Developing World: Challenges, Continuity, and Change. Politics \& Society 43: 463-470.

Rudra, Nita, and Stephan Haggard. 2005. Globalization, Democracy, and Effective Welfare Spending in the Developing World. Comparative Political Studies 38 (9): 1015-1049. https://doi.org/10.1177/0010414005279258.

Schmidt, Manfred G. 1982. Wohlfahrtsstaatliche Politik unter bürgerlichen und sozialdemokratischen Regierungen: ein internationaler Vergleich. Frankfurt/ Main, New York: Campus.

Schmitt, Carina. 2015. Social Security Development and the Colonial Legacy. World Development 70: 332-342. https://doi.org/10.1016/j.worlddev. 2015.02.006.

Stubbs, Paul. 2003. International Non-State Actors and Social Development Policy. Global Social Policy: An Interdisciplinary Journal of Public Policy 
and Social Development 3 (3): 319-348. https://doi.org/10.1177/ 14680181030033003.

Supiot, Alain. 2006. The Position of Social Security in the System of International Labor Standards. Comparative Labor Law and Policy Journal 27 (2): 113-121. Surender, Rebecca. 2013. The Role of Historical Contexts in Shaping Social Policy in the Global South. In Social Policy in a Developing World, ed. R. Surender and R. Walker, 14-36. Cheltenham: Edward Elgar Publishing. Surender, Rebecca, and Robert Walker, eds. 2013. Social Policy in a Developing World. Cheltenham: Edward Elgar.

van Kersbergen, Kees. 1995. Social Capitalism: A Study of Christian Democracy and the Welfare State. London, New York: Routledge.

van Kersbergen, Kees, and Philip Manow. 2009. Religion and the Western

Welfare State. In Religion, Class Coalitions, and Welfare States, ed. Kees van Kersbergen and Philip Manow. Cambridge, New York: Cambridge University Press.

Walkenhorst, Heiko. 2008. Explaining Change in EU Education Policy. Journal of European Public Policy 15 (4): 567-587. https://doi.org/10.1080/ 13501760801996741.

Wibbels, Erik, and John S. Ahlquist. 2011. Development, Trade, and Social Insurance. International Studies Quarterly 55 (1): 125-149.

Yeates, Nicola. 2009. Globalizing Care Economies and Migrant Workers: Explorations in Global Care Chains. Basingstoke: Palgrave Macmillan.

Open Access This chapter is licensed under the terms of the Creative Commons Attribution 4.0 International License (http://creativecommons.org/licenses/ by/4.0/), which permits use, sharing, adaptation, distribution and reproduction in any medium or format, as long as you give appropriate credit to the original author(s) and the source, provide a link to the Creative Commons licence and indicate if changes were made.

The images or other third party material in this chapter are included in the chapter's Creative Commons licence, unless indicated otherwise in a credit line to the material. If material is not included in the chapter's Creative Commons licence and your intended use is not permitted by statutory regulation or exceeds the permitted use, you will need to obtain permission directly from the copyright holder.

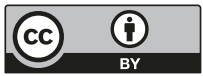

